\title{
Inventing 'infrastructure': tracing the etymological blueprint of an omnipresent sociotechnical metaphor
}

\author{
Justinien Tribillon ${ }^{\mathrm{a}}$
}

${ }^{a}$ The Bartlett School of Planning, University College London, London, United Kingdom

Email: j.tribillon@ucl.ac.uk ; ORCiD: 0000-0003-1099-3862 ; Twitter: @justinient ; Postal address: Bartlett School of Planning, Central House, 14 Upper Woburn Place, London, WC1H 0NN

\section{Acknowledgments}

I would like to thank Enora Robin, Claire Colomb, Cécile Trémolières for their invaluable advice and generous feedback on the different drafts of this paper as well as Jean Daniélou for the passionate discussions on the concept of infrastructure. I also wish to thank the participants of the international workshop 'Historical perspectives on urban infrastructure' that Enora Robin and I organised in April 2018 at University College London, and especially Dom Davies for their comments. The initial idea for this paper was developed for a seminar where I was invited to present my doctoral research at Fondation des Sciences de l'Homme in October 2017. I would like to thank Saskia Sassen, Véra Vidal and especially John Bingham-Hall for their invitation. Finally, I would like to thank Jérôme Denis, David Pontille, Roman Solé-Pomies and Daniel Florentin for their fruitful feedback on a final version of this paper.

\section{Funding sources}

This research did not receive any specific grant from funding agencies in the public, commercial, or not-for-profit sectors.

\section{Disclosure statement}

I declare no conflict of interest. 


\title{
Inventing 'infrastructure': tracing the etymological blueprint of an omnipresent sociotechnical metaphor
}

\begin{abstract}
This article proposes an archaeology of the concept of 'infrastructure', focusing specifically on a period ranging from 1842 until 1951, before the term entered the English language from French. In doing so, it contributes to an ongoing discussion on 'What does infrastructure really mean?' by deconstructing the omnipresent concept of 'infrastructure' as an expression of modernity that has crystallised a sociotechnical imaginary: a relation between technology, space and power. Indeed, our understanding of its etymological, epistemological and intellectual origins is patchy, based on repeated chronological mistakes and conceptual misunderstandings. To put it bluntly: we do not know how the word came to be. By unearthing the origins of 'infrastructure', this article aims to contribute to scholarly debates on the definition(s) of infrastructure in social sciences, urban studies, science and technology studies and infrastructure studies. It also wishes to contribute to ongoing debates taking place in the public sphere regarding what should count as 'infrastructure'. This paper's findings demonstrate a clear relation to Karl Marx's 'historical materialism'; the paper also analyses how the word evolved over a short period of time to become sociotechnical metaphor; finally, the paper demonstrates the emergence of a concept that linked engineering to larger socioeconomic concerns in the 1890s, well before the emergence of 'infrastructure' as a key concept of development economics in the 1950s.
\end{abstract}

Keywords: infrastructure; sociotechnical imaginaries; France; spatial metaphor; archaeology; Saint-Simonianism; materialism 
'Original forms of thoughts introduce themselves: their history is the only form of exegesis they can bear, and their destiny the only form of critique. ${ }^{1}$ Michel Foucault, 'Introduction' in Ludwig Binswanger Le Rêve et l'Existence (1955 my translation)

In a filmed remark at a virtual CEO summit on semiconductor and supply chain on 12 April 2021, U.S. President Joe Biden held a large iridescent electronic chip twice the size of his hand, waved it at the cameras from C-Span and said 'Chips, like the one I have here - these chips, these wafers, are batteries, broadband; it's all infrastructure. This is infrastructure.' And paused emphatically, before resuming his address in support of the CHIPS for America programme (Biden, 2021; and C-Span, 2021 for the video broadcast). The \$2 Trillion plan introduced by Joe Biden at the end of March 2021 has sparked a fascinating debate over "What "infrastructure" really means?' (Tankersley \& Smialek, 2021). Republicans have accused the Biden administration of neglecting 'real' infrastructure, like bridges and roads, by relying on a meaningless stretched-out definition of infrastructure as a 'trojan horse' for more public spending for Senator Mitch McConnell of Kentucky. Meanwhile, Democrats and supporters of a wider acceptation of 'infrastructure' have argued that anything that helps people carrying out their professional and personal lives in a productive and fulfilling

${ }^{1}$ All texts from French are my own translations. The same applies to the scarce Italian references that I use. In my translations, I have privileged faithfulness to style, and I have done my best to stick to the original punctuation, capitalisation, formatting and emphasis. Original citation: 'Les formes originales de pensée s'introduisent elles-mêmes : leur histoire est la seule forme d'exégèse qu'elles supportent et leur destin, la seule forme de critique.' 
way should be considered infrastructure and qualify for funding through the plan. Economist Cecilia Rouse, Chair of the White House Council of Economic Advisers illustrates this position saying: 'I couldn't be going to work if I had to take care of my parents. How is that not infrastructure?' (Tankersley \& Smialek, 2021).

'Infrastructure' is a powerful, omnipresent word. And yet, we barely know how the word came to be. We do not know how it was born. We barely know when. We have no critical understanding as to why it emerged. We live in an 'infrastructural age' (Steele \& Legacy, 2017) but there is no comprehensive research on the word's etymological, semantical and intellectual journey(s) before it entered the English language in the 1950s. The most ambitious contribution on this topic is Ashley Carse's keyword essay on infrastructure (Carse, 2017; see also van Laak, 1999; Rankin, 2009). Carse’s research offers an invaluable input into our understanding of 'infrastructure', proposing an intellectual and etymological introduction to the concept, taking his reader from its origins to present-day social theories. 'Infrastructure might be characterized as a plastic word that has been stripped of its former specialized meaning and can now fit nearly any circumstance. Seen in this way, the term's vagueness is not a weakness, but central to its utility in a wide variety of projects.' (Carse, 2017, p. 28 my emphasis). But Carse's essay only touches on the word's emergence in 1880s France, focusing instead on its introduction to the English lexicon from the 1950s onwards, without establishing with precision when, how and why the word came to be.

This paper offers to bridge that gap by providing an archaeology of 'infrastructure', focusing specifically on a period ranging from 1842 until 1951. By 
archaeology ${ }^{2}$ I mean a multidisciplinary study with language at its core that aims at 'reveal[ing] a positive unconscious of knowledge: a level that eludes the consciousness of the scientist and yet is part of a scientific discourse, instead of disputing its validity and seeking to diminish its scientific nature' (Foucault, 1971, p. xi). With this archaeology, I wish to contribute to a 'thicker' understanding of 'infrastructure that will allow critics and scholars to challenge 'infrastructure' as an omnipresent expression of modernity that has crystallised a sociotechnical imaginary, a relation between technology, space and power.

I will do so by explaining how the word appeared in nineteenth century France as obscure jargon at the crossroad of finance and engineering; how socialist circles elevated it to a metaphor at the turn of the century; and how it morphed once again to become a successful concept in the first half of the twentieth century before entering English in the wake of World War II (WWII). In order to proceed with this archaeology, this paper will explore etymology, semantics and translations in French and English, with short detours in Italian and German. Using digitised corpora of texts, namely the Google Books database ${ }^{3}$ and the digital platform of the Bibliothèque Nationale de France (France's National Library), ${ }^{4}$ it will review a large selection of occurrences of 'infrastructure' that appeared from the 1850s until the 1960s in the French language. It

${ }^{2}$ Archaeology is another popular spatial metaphor in social sciences and philosophy, that relates to what is 'below' in relation to what is 'above'. See Paltrinieri (2015).

${ }^{3}$ Google Books is available at https://books.google.com/. In October 2019, Google declared they had recorded 40 million books in 400 languages. See Google (2019).

${ }^{4}$ The Bibliothèque Nationale de France holds France's legal deposit. As of February 2020, its digital library, Gallica, held 6 million scanned documents. See Gallica (n.d.). 
will cross-reference these occurrences with contemporary texts on engineering, social sciences, policy and politics. At the core of this paper is the hypothesis that 'infrastructure' became the rich concept we understand today, from the odd meeting of socialism, railway expansion, engineering and capitalism.

\section{'Infrəstrıktృə: a calque word from French to English}

A technical jargon apparently borrowed from development economics, the Oxford Dictionary defines 'infrastructure' as 'The basic physical and organizational structures and facilities (e.g. buildings, roads, power supplies) needed for the operation of a society or enterprise.' Comedian John Oliver (2015) adds wittingly that 'infrastructure [is] basically anything that can be destroyed in an action movie.'

'Infrastructure' is a popular expression because it is evocative: it encapsulates modernity - the association of capital, statal project, and technology. Arguably, we collectively share a networked imaginary where our social and economic structures rest on a series of interdependent systems that enable them to function: the roads and rail tracks that bring us to work in the morning, the internet and mobile networks that allow us to watch Netflix on our laptops, our power-grids and water pipes.

'Infrastructure' has morphed to become sociotechnical metonymy. This metonymic might is why the Morandi Bridge collapsing in Genoa was not only the tragic downfall of a bridge but also that of an Italian national myth (Mattioli, 2019). This metonymic might is why the screenwriters for Hollywood 'blockbuster'5 movies

\footnotetext{
${ }^{5}$ The Oxford Dictionary also teaches us 'blockbuster' is a term the English language inherited from WWII. A blockbuster is a bomb so powerful it can raze a whole neighbourhood to the ground.
} 
never miss a chance to burn down roads, bridges, dams, levies, airports, power-grids (Keane, 2006). Infrastructures are symbols and supports of social imagination. They are myths that act as signs (Barthes, 1957).

Today's critical approach to infrastructure in social theories has its intellectual roots in science technology and society studies (Hughes, 1983; Bijker, Hughes, \& Pinch, 1987; Castells, 1989, 1996; Latour, 1991, 1992; Latour \& Hermant, 1998), in the question of 'artefacts as politics' (Winner, 1980) and in the study of 'information infrastructure' (Bowker, 1994; Bowker \& Star, 1999; Bud-Frierman, 1994; Edwards, 1998; Neumann \& Star, 1996; Star, 1999; Star \& Ruhleder, 1996). As Paul Edwards recently pointed out in a series of tweets on the history of infrastructure in sciences and technology studies (STS), most of the earlier works, such as Hugues's, did not use the term 'infrastructure', but instead 'large technical systems' (Paul N. Edwards, 2021). In a parallel journey that took place in architecture critique on one hand, history of architecture, engineering and technology on the other, the concern for infrastructure arose from a focus on the engineer as designer and urbanist (Banham, 1988; Bucciarelli, 1994; Picon, 1992a, 1992b). In the disciplines concerned with 'space', the concept of infrastructure gained momentum in the 2000s-2010s as scholars critiqued the 'modern infrastructure ideal', the failures of 'black-boxed' networks, and the 'symbolic power' of infrastructure (Coutard, 1999; Graham \& Marvin, 2001; Kaika \& Swyngedouw, 2000). Academics also analysed infrastructure in relation to 'social imagination' (Picon, 2007, 2018) and read it as 'poetics' (Larkin, 2013). An 'anthropology of infrastructure' has focused on the relation to human experience and social practice, and even on 'people as infrastructure' (Hall, King, \& Finlay, 2017; Simone, 2004, 2021) by 'foreground[ing] the urban backstage to reveal the sociality of roads, pipes, cables, broadband, code and classification and the enrolments of the sociotechnical systems that 
they are part of' (Amin, 2014, p. 139). This literature has mostly, but not solely, focused its research on the Global South, looking for instance at sanitation, negotiated access to infrastructure, and mechanisms to cope with the lack or absence of infrastructure (Amin, 2014; Björkman, 2015; Gandy, 2014; Maringanti \& Jonnalagadda, 2015; Renu, McFarlane, \& Graham, 2014; Silver, 2014; Simone, 2015; Trovalla \& Trovalla, 2015). I have limited the scope of my literature review to science and technology studies (STS), anthropology and urban studies, yet infrastructure has also been a fundamental concepts for development economics (Rankin, 2009), and military strategies (especially in relation to cost) when they appeared from as early as 1951 as we will see later in this paper.

As an anecdotal yet revealing evidence of the momentum it gained in Englishspeaking social sciences over the last two decades, one can observe the number of occurrences of the word 'infrastructure' in the programmes of the American Association of Geographers' (AAG) annual meetings - arguably the largest gathering of geographers and other social scientists interested in space: it increased from 7 mentions in 2001 to 162 in 2019 (American Association of Geographers, 2001, 2019). A concept that had barely emerged two decades ago is now omnipresent.

Fourteen letters and nine consonants. The word's pronunciation, in English especially, is so difficult that the Internet offers countless video tutorials explaining how to correctly go about enunciating 'Infrestrıkt əə. (Accent's Way English with Hadar, 2017; Collins A-Z, 2017; Superholly, 2018) Despite these hurdles, the complexity of its pronunciation is inversely proportional to the word's ubiquity.

'Infrastructure' is a calque from French. According to the Oxford Dictionary of English Grammar a calque, or loan translation, is 'An expression adopted by one 
language from another in a more or less literally translated form.' (2014) It belongs to a long list of words, that includes technical terms, borrowed from French and brought into the English lexicon in the early twentieth century—such as 'limousine', 'fuselage', 'supersonic'(Schultz, 2012). Infrastructure does not have the ancient history of apparent synonyms like 'network' (sixteenth century in English, fifteenth century for the French réseau). ${ }^{6}$ Nor was it invented to name a new technological invention such as the computer: ordinateur in French but often a calque word in other languages, e.g., computadora in Spanish, computer in Dutch and German, компью́mep ('komp'yúter') in Russian.

As a calque, 'infrastructure' exists in pretty much the same form and same meaning in an endless list of languages across different families, most especially IndoEuropean. A few examples (with no ambition for exhaustivity): Infrastruktur (German), infraestructura (Spanish), infrastruttura (Italian), infrastructuur (Dutch), but also инфраструктура ('infrastruktura', Russian). And of course, infrastructure in French.

At the outset, one can emit three hypotheses when considering this similarity across different languages. (a) That 'infrastructure' is a recent word; (b) that 'infrastructure' is a technical term that was transmitted across languages via technical and specialist literature; (c) that it was adopted extremely quickly (within decades, if not years) by these different languages and via very specific semantic channels (e.g., an industry, a political network, a trade — which indeed takes us back to the second hypothesis).

\footnotetext{
${ }^{6}$ On the conceptual differences between 'network' and 'infrastructure' see Picon (2014).
} 
Figure 1 and Figure 2 illustrate the popularity of 'infrastructure' (and its translations listed above) in German, French, Italian and English from 1800 until 2000. The data is extracted from Google Books database and represent trends in the use of a given word or expression across time in a given language. ${ }^{7}$ Figure 1 represents the data from 1800 to 2000 , Figure 2 focuses on a period from 1800 to $1950 .{ }^{8}$ Before the 1880 s, the word is quasi invisible across these languages. The scattered surges observable before that decade are mainly anomalies: for instance, the spike in German in the $1870 \mathrm{~s}$ is due to one occurrence in an 1873 book. Looking closely, it appears the book was published in 1973, and not 1873: a simple database error. The term 'infrastructure' clearly takes off from the 1880 s onwards in French. Its progression and popularity remain fairly modest — though much more used in French that in any other languages until the 1940s where the data reveal a steady and quick progression throughout the 1940s, 50s and 60s. The German tongue appears to adopt 'Infrastruktur' in the 1950s whilst the English language makes it its own from the 1960s onwards.

${ }^{7}$ On the relevance of Google Books database and digitised text corpora, see Sparavigna and Marazzato (2015); Michel et al. (2011).

${ }^{8}$ The data was extracted in August 2019 and reviewed in April 2020. The data was extracted from Google Books NGram Viewer (https://books.google.com/ngrams). The search performed was case-sensitive and with a smoothing of ' 0 '. The terms searched were 'infrastructure' from the corpus English (2012), 'infrastructure' from the corpus French (2012), 'infrastruttura' from the corpus Italian (2012) and 'Infrastruktur' from the corpus German (2012). The data was then extracted following the method presented in Filter (2017). The softwares Numbers version 10.0 (6748) and Adobe Illustrator 24.0.3 were used to clean and visualise the data in a diagram. 


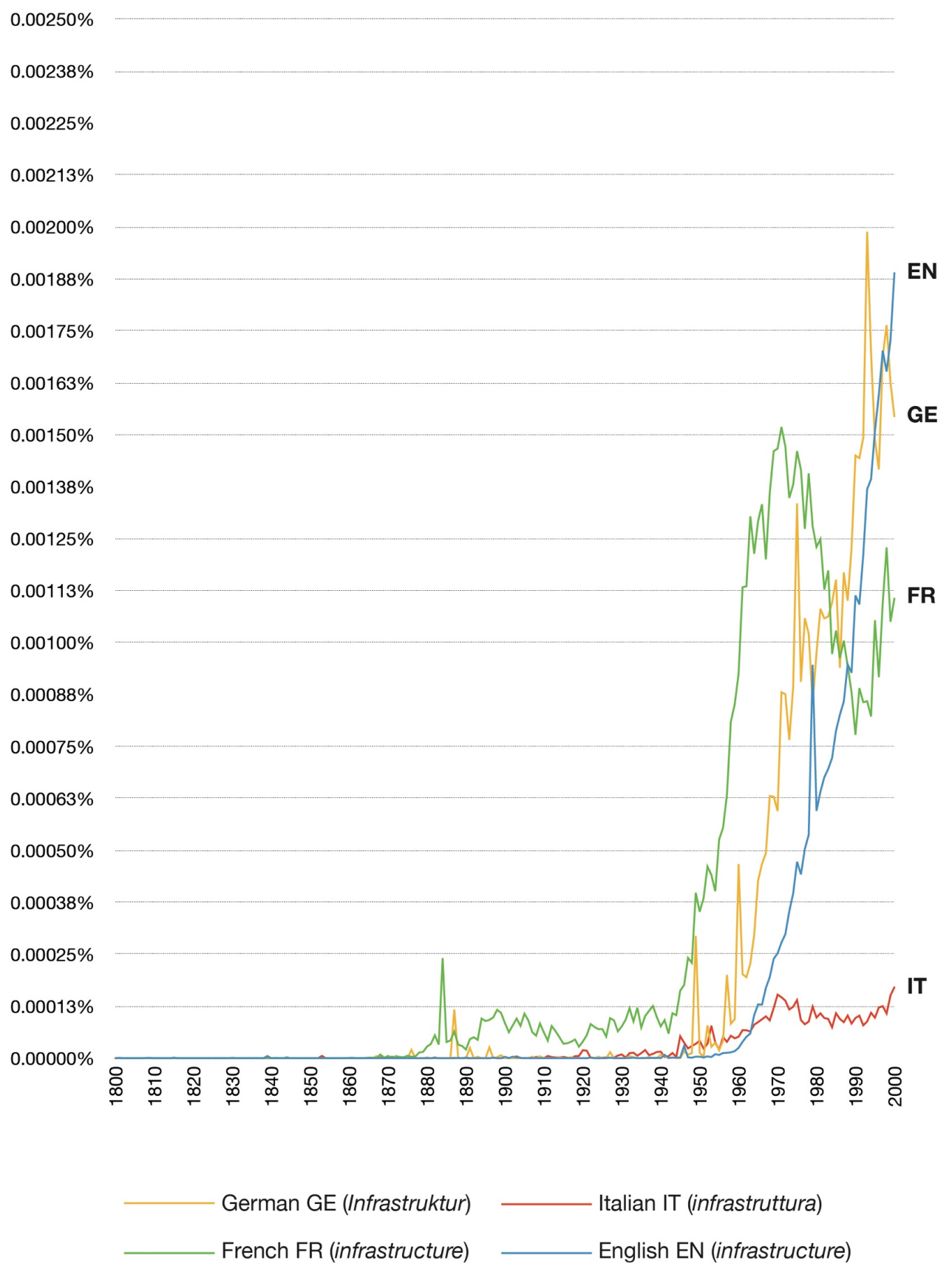

Figure 1 Occurrences of 'infrastructure' in English (infrastructure), German (Infrastruktur,) French (infrastructure), Italian (infrastruttura) from 1800 to 2000. 


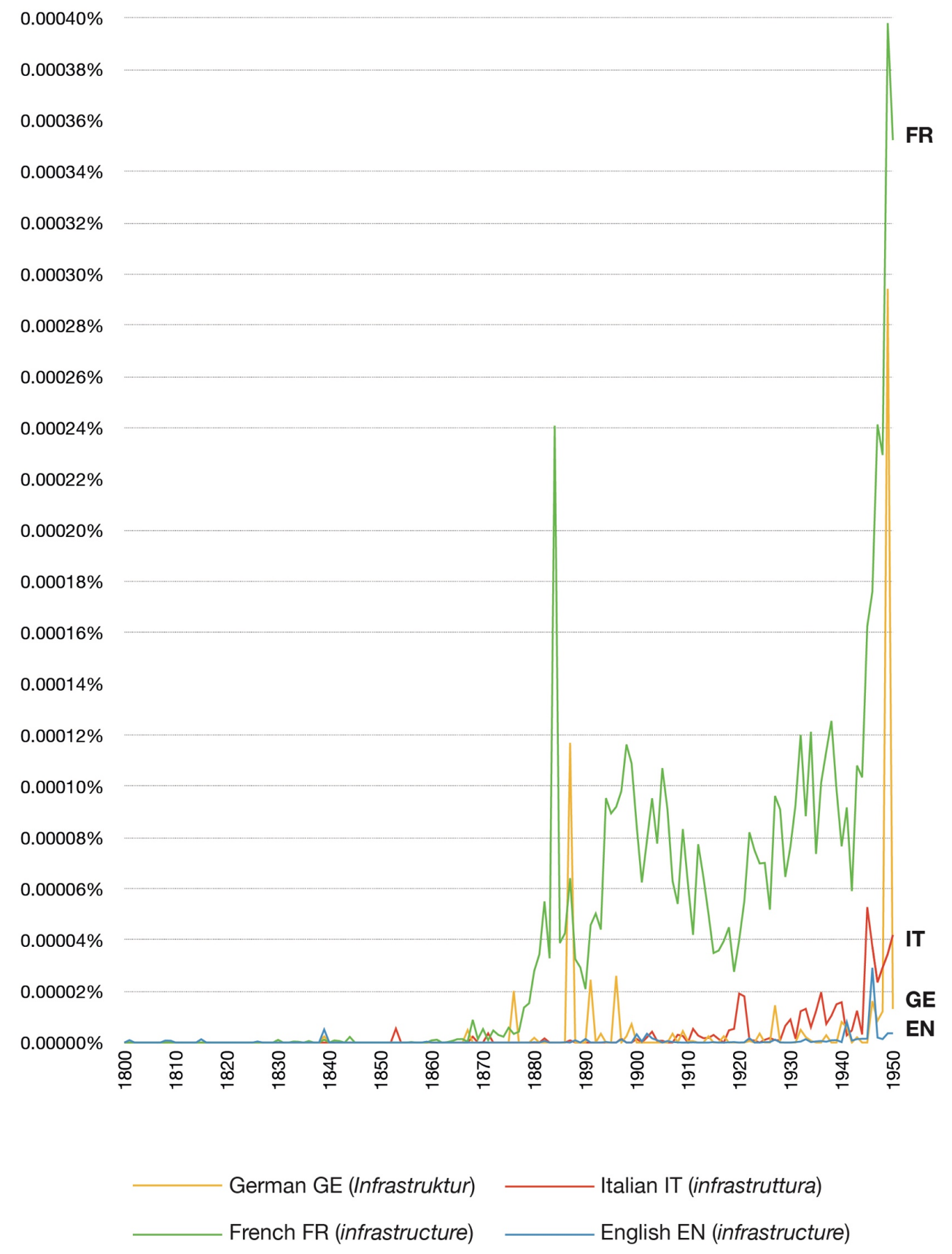

Figure 2 Occurrences of 'infrastructure' in English (infrastructure), German (Infrastruktur,) French (infrastructure), Italian (infrastruttura) from 1800 to 1950. 
Google Books data offers an interesting insight into the journey of 'infrastructure' and its variants across these different languages. Yet, the demonstration has its shortcomings, the most important one being that it does not reveal the meaning of infrastructure across time and tongues.

It is usually said that 'infrastructure' enters the English language in 1927. Several reference dictionaries such as the Oxford English Dictionary mention that date and so do most authors who have traced the etymology of the word. As Carse explains, this is a first mistake (Carse, 2017, p. 29). 'Infrastructure' is used in English-language publications dating back to at least 1879 , referring to railway projects in France and Spanish-speaking countries. Yet, throughout the nineteenth century and first half of the twentieth century, the term remains extremely rare in English. It is rare even amongst the specialised literature dedicated to railway, and it is but inexistent in general English. This absence is confirmed by the Google Books data presented earlier, and by searches I conducted via the online search engines of the Library of Congress and the British Library that return anomalies or no results. Most importantly, its meaning and its use are circumscribed to administrative law and civil engineering, far from its present-day definition.

According to Carse, 'infrastructure' only entered a general English dictionary in 1963 (the Webster's Seventh New Collegiate Dictionary), seventy-seven years after its first feature in a French reference dictionary (Carse, 2017, p. 33; for the first entry in a French dictionary, see Littré \& Devic, 1886). Also, its meaning had started a metamorphosis from a very precise word used by engineers and financiers, to the rich, equivocal and ubiquitous concept it has become today. It is the journey of this intellectual transformation that this paper will now study, for this journey has so much 
to reveal about how we built the modern sociotechnical imaginaries that 'infrastructure' has crystallised.

\section{First stop: railway and capitalism in $19^{\text {th }}$ century France}

The birth of 'infrastructure' took place in two steps. The concept came first, the word only second. On 11 June 1842, King Louis Philippe of France signed a bill of law to stimulate the expansion of railway across the country and indeed Europe. France was lagging well behind the United Kingdom, whose railway industry was thriving, emboldened by the Railway Mania (Robb, 1992; Davies, 2015; for the bill of law see Royaume de France, 1842).

The bill delivered what we would call today a strategic design for the expansion of railway across France, listing out the connections to be built in the coming years. The star-shaped design with Paris in its centre, known as 'étoile de Legrand', still structures France's railway network today.

More than the expression of a spatial project, the bill also looked at addressing what was then perceived as the biggest handicap for French railway expansion: money, or lack thereof. The bill did so by devising an interesting double dichotomy, above/below and private/public, here to stimulate the financing and building of new railway lines. Indeed, the bill decreed that the State and local authorities would bear the following costs: land acquisition, levelling, erection of bridges and opening of tunnels. On the other hand, private operators were to pay for the installation of railway tracks, the cost of exploitation and maintenance, the purchase and repair of rolling stocks. In a nutshell: the cost of what sat below the railway tracks was to be borne by the 'public sector' (please forgive this anachronism), the tracks and what sat above was the domain of private actors.

\footnotetext{
Inventing 'infrastructure': tracing the etymological blueprint of an omnipresent sociotechnical metaphor (preprint) Justinien TRIBILLON, The Bartlett School of Planning, University College London — j.tribillon@ucl.ac.uk
} 
The law of 1842 was but the tip of a steamy iceberg. Since the 1820 s and the successful coupling of railway and steam technologies - the premise of a revolution in rail transport - the financing, modes of exploitation, maintenance of railway lines had led to heated debates amongst intellectuals, politicians and industrialists (see for instance Cronier, 1847; Proudhon, 1845; Chevalier, 1852a). The development of railway brought fundamental economic and political challenges - which to a certain extent remain debated today - on profitability, the possibility of balancing the cost of construction and the cost of exploitation, but also on the statute of railway workers, their rights and duties, etc. At the core of this complex discussion was the issue of if and how should the State intervene.

As commentators started to understand the revolutionary impact of modern railway on humanity's relationship to space and time, debates became all the more ardent. 'A modern philosopher has said The golden age that some blind tradition had located in the past is indeed ahead of $u s^{\prime 9}$ writes prominent intellectual and political figure Michel Chevalier (1806-1879) in his economy class at Collège de France in 1852, quoting Henri de Saint-Simon without directly mentioning his name. On the socio-spatial impact of railway, he adds:

The European will have an estate in New Zealand or Australia, the same way 200 years ago a French lord had land in Provence and an English baron a castle in Scotland. Two friends, parting in Paris, will set their next meeting in Calcutta or Mexico, without finding this the least extraordinary. [...] From Rome to Edinburgh, we will be neighbours. [...] And the wise will understand that instead

\footnotetext{
${ }^{9}$ Original citation: 'Un philosophe moderne a dit : L'âge d'or qu'une aveugle tradition avait mis dans le passé est devant nous.
} 
of being shrunk and belittled, our planet will then be fecundated. ${ }^{10}$ (Chevalier, 1852b, pp. 13-14)

To fully grasp the historical context, it is also crucial to bear in mind that this technological invention and the debates on its development and implementation took place within an ebullient 'long' $19^{\text {th }}$ century: between 1800 and 1870 , France would go through seven different political regimes (namely three republics, two empires, two monarchies). Countless political-cum-philosophical movements, sects and factions emerged and fought—metaphorically and often physically. Amongst them, the immensely influential followers of Saint-Simon.

Saint-Simonianism was a complex intellectual movement born in the first half of the $19^{\text {th }}$ century. Named after Henri Vouvroy de Saint-Simon $(1760-1825)$, its core ideology rested on the belief that technological progress would change society for the better, bringing happiness, emancipation and freedom. Saint-Simon's thought is commonly identified as a form of utopian socialism with its intellectual foundations in $18^{\text {th }}$ century French materialist philosophy. After Saint-Simon's death, the movement stemmed into different sects_-including an influential church led by Prosper Enfantin (1796-1864) — that promoted varied readings of Saint-Simon's thought. Karl Marx

${ }^{10}$ Original citation: 'L’Européen aura une propriété dans la Nouvelle-Zélande ou l'Australie aussi naturellement qu'un seigneur de la cour de France avait, il y a 200 ans, une terre en Provence ou un baron anglais un château en Ecosse. Deux amis, en se séparant à Paris, se donneront rendez-vous à Calcutta ou Mexico, sans que cela paraisse extraordinaire. [...] De Rome à Édimbourg, on voisinera. [...] Mais le sage pensera qu'au lieu d'avoir été rapetissée et ravalée, notre planète aura été fécondée.' 
(1818-1883) and Friedrich Engels (1820-1895) considered Saint-Simon as one of the most influential intellectuals of socialism (see for instance Engels, 1908, pp. 56-64). Yet, somehow confusingly (from our contemporary point of view), the Count of SaintSimon was also the flagship thinker for proponents of free-trade and capitalism. In various forms, and borne by miscellaneous stakeholders, Saint-Simon's ideas were significantly present in $19^{\text {th }}$ century Europe and especially France, most especially amongst its elites (engineers, economists, intellectuals, capitalists), those that were not yet called technocrats.

Amongst these foremost figures of Saint-Simonianism were Emile (1800-1875) and Isaac Pereire (1806-1880). The Brothers Pereire were then some of the most powerful bankers in Europe and key actors in the railway industry, in France and abroad (Vajda, 2008; Davies, 2015). In an 1857 epic competition between Europe's most powerful bankers and politicians, the syndicate they led won the mandate to found Russia's main railway company. For historian Alfred Rieber, in typical Saint-Simonian fashion, the Pereires' ambition was both a financial and 'civilising' enterprise:

Correspondence from the private banking archives of the Pereire and Hottinguer firms make clear that $[\ldots]$ the French bankers' motives were not to make a quick killing on international money market [...]. As Isaac Pereire wrote to his brother in July 1856: 'We are going to develop a virgin territory whose hinterland, to some degree unexplored, contains enormous natural resources. It is only necessary to link up the productive centres with the ports of the country in order to extract products which will spare Europe from (any) scarcity.' Railroads would bring Russia into the mainstream of European civilization. (Rieber, 1973, p. 380) 
In classic materialist Saint-Simonian fashion, the Brothers Pereire had linked capital, technological achievement and the progress of humankind. There was a political and civilizational project embedded in financing and eventually laying the tracks of European railways.

The legal document signed between Alexandre II of Russia and the consortium led by the Brothers Pereire, that marked the foundation of the Great Company of Russian Railways in January 1857 used for the first time the term infrastructure and the dualism infrastructure/superstructure. This is the first ever mention of infrastructure I could find in French and it espouses the definition established in 1842. The second article of this Russian railway company states that:

\section{Art. 2}

The concession for the railway from St Petersburg to Warsaw incudes the land, the levelling and the bridges and tunnels [ouvrages d'art ${ }^{11}$, the infrastructure and the superstructure of the railway tracks with their associated products such as the buildings and stations, loading and unloading bays, constructions at venues of arrival and departure, surveillance booths, rolling stocks, providing of fuel and other materials, mobile and immobile machines, locomotive, carriages, tools, in such a quantity and in such a state that they will be ready for the opening of the

${ }^{11}$ Travaux d'art, literally translated as 'works of art' is a very difficult term to translate faithfully in English. It describes all engineering feats in the building or roads, railways, etc. It mainly refers to bridges and tunnels. 
railway connection without further delay. ${ }^{12}$ (Grande société des chemins de fer russes. Documents officiels, 1858, p. 11-my emphasis)

One notices here that the Pereire consortium fully replaced the Imperial Government in the provision of both infrastructure and superstructure. The same year, ${ }^{13}$ a newspaper used for the first time the word 'infrastructure' to report the creation of the Russian Railway Company (Janets, 1857).

This dualism between what is below the railway and funded by the State, and what sits above and financed by private actors established in the law of 1842 now had acquired names of their own: infrastructure and superstructure. Rarely used and never applied to railway before, 'superstructure' is a term that had existed since the $17^{\text {th }}$ century. In French and in English, it describes the superfluous element of a building, a play, a book and is used by Voltaire in 1764 for instance. On the other hand, I have found no evidence that 'infrastructure' existed, at all, and in any form, before this mention in 1857.

${ }^{12}$ Original citation: 'La concession pour ce qui concerne le chemin de Saint-Pétersbourg à Varsovie comprend les terrains, les terrassements et les ouvrages d'art, l'infrastructure et la superstructure de la voie de fer avec leurs dépendances immobilières et mobilières, telles que bâtiments des stations, places de chargement et déchargement, constructions aux lieux d'arrivée et de départ, maisons de gardes et de surveillance, avec leur matériel et mobilier, approvisionnement de combustible et autres matériaux, machines fixes et mobiles, locomotives, wagons, outillage en telle quantité et tel état qu'ils se trouveront à l'époque de la remise du chemin de fer à la Compagnie et sans en rien distraire.'

${ }^{13}$ The official document quoted above is published in 1858 but written and signed in January 1857. 
This discovery brings two fundamental questions that I have not been able to answer for now: amongst the redactors of this contract, who coined this term? And why? There is also a small possibility that the term came from Russian. At this stage of the demonstration, it is also interesting to note that, the opposition infrastructure/superstructure does not come from engineering per se, but from its financing. Infrastructure is the invention of financiers invested by an industrialist utopia, not that of engineers.

Within a few years, the word blossomed. By the 1870s, it had become a staple vocabulary to describe the nexus State/capital/engineering. ${ }^{14}$ Most commonly described as a term of civil engineering, it would have been more accurate to refer to infrastructure as pertaining to financing and administrative law. I have also studied the syllabi and students' notes of the School of Bridges and Roads-France's principal school for engineers and civil servants in charge of designing and delivering railwaysand could not find any mention of 'infrastructure' until the late $19^{\text {th }}$ century ${ }^{15}$. Again, this absence tends to confirm the term was not one initially cherished by engineers, but one carried on by administrative law, economics and finance.

${ }^{14}$ Most, if not all papers and that trace the history of 'infrastructure', as well as reference dictionaries, mention that the word is used for the first time in French in 1875 by the Journal Officiel (the official publication for laws, decrees, etc.). I have showed that this repeated assumption is false.

${ }^{15}$ The first mentions of 'infrastructure' I could find where in the students' handwritten notes for the academic year 1891/1892 for the class of Charles Bricka on railroad engineering. See Bricka (1891, p. 4). 
Infrastructure entered the Littré dictionary in an 1886 supplément to the reference glossary whose first volume had been published in 1863 . The publication front cover mentions that the 1886 supplementary volume to the dictionary 'Holds a great number of terms of the arts, science, agriculture etc. and all kind of neologisms illustrated with examples. ${ }^{16}$ Infrastructure is defined as:

Term of civil engineering. Name given to the land, the levelling work and highway structure [travaux d'art] of a railroad. ${ }^{17}$ (Littré \& Devic, 1886, p. 200)

Subsequently, a Dictionnaire Législatif et Réglementaire des Chemins de Fer [Legal and Reglementary Dictionary of Railways] published in 1887 gives a more exhaustive definition whilst also clearly introducing the complementary notion of superstructure.

$1^{\circ}$ infrastructure

Land purchase;

Levelling work;

Bridges;

Railway line guard's house;

Level crossing, paving, fences.

$2^{\circ}$ superstructure

${ }^{16}$ Original citation: 'Supplément renfermant un grand nombre de termes d'art, de science, d'agriculture, etc. et de néologismes de tous genres appuyés d'exemples.'

${ }^{17}$ Original citation: 'Terme de génie civil. Nom donné aux terrains, aux terrassements et aaux travaux d'art d'une voie ferrée.'

Inventing 'infrastructure': tracing the etymological blueprint of an omnipresent sociotechnical metaphor (preprint) Justinien TRIBILLON, The Bartlett School of Planning, University College London — j.tribillon@ucl.ac.uk 
Ballast, support, railway tracks;

Track installation;

Fences of all kind $[\ldots]$;

Buildings of all nature for exploitation; stations, workshops, etc;

Telegraph, signals, mileposting..., etc. ${ }^{18}$ (Palaa, 1887, p. 741)

Within a few years, the term infrastructure had also started to appear in publications related to architecture and archaeology—-then considered a single discipline (Alonzo, 2018, pp. 103-107). It was used in a literal and non-metaphorical way to describe the foundation or buried structure, man-made or natural, of an edifice, a building, or any structure like a cave, or a monument (e.g. Société languedocienne de géographie, 1890, p. 131; Revue archéologique, 1893). Novelist Jules Verne, one of the 'Father of Science Fiction', also used the term in the same way, in Le Chateau des Carpathes (1892) and L'Île à helices (1895).

The journey of 'infrastructure' could have stopped there: a useful yet highly specialised term whose relevance was circumscribed to engineers, architects, civil servants and investors. Yet, in the late 1890s, the jargon tinged with Saint-Simonianism escaped its fate to reach a whole new audience.

${ }^{18}$ Original citation: ' $1{ }^{\circ}$ Infrastructure. Acquisitions de terrains ; Terrassements ; Ouvrages d'art ; Maisons de gardes et de cantonniers ; Passages à niveau, pavages, barrières. $2^{\circ}$ Superstructure. Ballast, supports, traverses, rails ; Pose de la voie ; Clôtures de toute espèce [...] ; Constructions de toute nature se rattachant à l'exploitation ; bâtiments de gares, ateliers, etc. ; Télégraphe, signaux, poteaux kilométriques..., etc .' 


\section{Take a left turn: historical materialism and socialist literature transform 'infrastructure'}

In 1859, Karl Marx published Zur Kritik der Politischen Ökonomie (Marx, 1859).

Today, most commentators agree that, with the notable exception of the preface dedicated to historical materialism, this opus is a minor work mostly because all of the research presented in 1859 was reworked, rewritten, enriched and eventually published from 1867 until 1894 in Marx’s magnum opus Das Kapital (Marx, 1867, 1885, 1894). In Europe, Marx's reputation as a leading political and intellectual figure had grown, slowly yet steadily, as translations of his work were released (Marx, 1872, 1879, 1887; The Capital was published in 1872 in Russian and French, in 1879 in Italian, in 1887 in English. - Resis, 1970). In France, the German thinker was initially commented amongst economists before truly emerging posthumously as a foremost intellectual in the 1890s. From 1895, his reputation grew beyond economics. Then, French intelligentsia and especially the new discipline of sociology, became mainly interested in Marx's conception of history (Cahen, 1994, 2011).

Marx's understanding of historical materialism is presented in a clear, short and compelling argument in the preface of his 1859 book. In a few words, it is the idea that an economic and technological base or foundation, shapes the politics and ideology of a superstructure. It clearly traces a relationship between technological or material elements and social consciousness. In Karl Marx’s words:

The general conclusion at which I arrived and which, once reached, became the guiding principle of my studies can be summarized as follows. In the social production which men carry on they enter into definite relations that are indispensable and independent of their will; these relations of production [Produktionsverhältnisse] correspond to a definite stage of development of their 
material powers of production. The sum total of these relations of production constitutes the economic structure [Struktur] of society—the real foundation [die reale Basis], on which rise legal and political superstructures [Überbau] and to which correspond definite forms of social consciousness. (Marx, 1904, p. $11-$ my emphasis)

There are several key terms in Nahum Isaac Stone's (1873-1966) first English translation of this text that I have highlighted and put next to the original version in German: most especially 'Struktur', 'reale Basis', and 'Überbau'. They are key terms to bear in mind.

When the second edition of Zur Kritik der Politischen Ökonomie came out in German in 1897, the work of Marx was in high demand (Marx, 1897). Two translations in French based on the second edition would be published in 1899 and 1909 (Marx, 1899, 1909). None of them used the term of infrastructure. Yet from the late 1890s onwards and throughout most of the $20^{\text {th }}$ century, the denomination infrastructure vs superstructure became a convention of French Marxist semantics (whilst English-speaking scholars would prefer the much more accurate base vs superstructure). From Henri Lefebvre (e.g., 1934) to Louis Althusser (e.g., 1965), all francophone students of Marx embraced the semantical canon of infrastructure and superstructure. Michel Foucault, in an interview with Paul Rabinow, explained how 'in our student days, people of my generation were brought up on these two forms of analysis - one in terms of the constituent subject, the other in terms of the economic, in the last instance, ideology and the play of superstructures and infrastructures' (Foucault, 1984, p. 65). 
In their 1982 Dictionnaire Critique du Marxisme, Labica and Bensussan set the record straight: for the infrastructure entry they note it is 'unused' and 'rare': 'This word whose extension took place well after Marx and Engels, is not a concept of the theory. See: Base. ${ }^{19}$ (Labica \& Bensussan, 1982, p. 596) And they write in the definition of base:

One should not prefer infrastructure [to basis], following the economics tradition that has prevailed rapidly and durably and whose perceived reciprocity with that of superstructure leads one to lose that there is an internal homogeneity to the structure, between base and superstructure, that should not be limited to simple causality. ${ }^{20}$ (Labica \& Bensussan, 1982, p. 93- original emphasis)

While no contemporary translation of Marx's theory of historical materialism in French ever used the word infrastructure to translate the German Basis, French students of Marx - followers or contradictors - have, throughout the $20^{\text {th }}$ century adopted infrastructure to discuss what would become one of the key concepts of one of the key theorists of this century. This term, infused with the utopian socialism of Saint-Simon, had metamorphosed dramatically to become a topos of Marxist literature. It is also

${ }^{19}$ Original citation: 'Ce mot dont l'extension est bien postérieure à Marx et Engels, n'est pas un concept de la théorie. Voir : Base.'

${ }^{20}$ Original citation: 'Il ne convient donc pas de préférer [à base], avec la tradition économiste qui prévaudra rapidement et durablement dans le marxisme, le terme d'infrastructure dont l'apparente réciprocité avec celui de superstructure fait perdre de vue qu'il y a une homogénéité interne à la structure, entre base et superstructure, qui ne se laisse pas réduire à la simple causalité.' 
worth noting that at the time, its literary value was almost immediately disputed — was Marx's infrastructure to be considered literally or metaphorically? Back to this paper's principal concern: if none of Marx's translators ever used infrastructure as a translation for Basis, then who did? And what impact does it have on the construction of a modernist performative sociotechnical metaphor where technological networks shape and support social groups?

The meaning of infrastructure changed abruptly in the 1890s. Over the course of two years and a handful of articles, all directly written or bearing the mark of one individual, the term infrastructure was transformed to reach a new purpose. As I mentioned earlier, the French intelligentsia's focus in the 1890s was mainly on Marx's theory of historical materialism. Yet, a key text was missing. The preface of Zur Kritik der Politischen Ökonomie was not available in French until its first translation published in 1899. The debate was fuelled by French commentators_-for instance the 1895 lecture delivered by Jean Jaurès (1859-1914) with a response by Paul Lafargue (1842-1911) (Jaurès \& Lafargue, 1895) - and what they knew of Marx and Engel's work (via translations, the reading of original texts in German, correspondence with Marx, Engels or their relatives, pamphlets, etc.). Across the Alps, historical materialism was all the rage where Italian scholars of importance, such as Antonio Labriola (1843-1904) and Benedetto Croce (1866-1952) had published a series of books and articles on this topic.(e.g., Labriola, 1896a; Croce, 1898, 1900)

Socialist circles across Europe were well connected, even more so for Italy's and France's. When Labriola published Del materialismo storico. Dilucidazione preliminare with Loescher in Rome in 1896, the book was instantly read and 
commented in France, and a translation was ready within a few months (Labriola, 1896a, 1897). The book had a significant intellectual impact, and was read far and wide, well beyond the usual socialist coterie (Cahen, 2011). In the French translation of Labriola's book we find several occurrences of 'infra-structure'(Labriola, 1897, p. 182) and 'infrastructure'(Labriola, 1897, p. 172). One cannot help but notice the different spellings. Typographical errors were not uncommon in the socialist literature at the time, published very quickly and with limited means. Yet, this irregularity would tend to reinforce the idea of a peculiar word whose spelling had not reached its final state. Furthermore, going back to the original Italian text, we find that infrastructure was not used to actually translate the Italian infrastruttura, as we could have expected. Instead, infrastructure was used as a translation of sottostrato, more accurately translated as 'substrate'. Therefore, the choice of Alfred Bonnet (1866-1933)—both publisher and translator - to go for infrastructure was not justified by the Italian text, instead he demonstrated some creative licence in the matter. And a trail of evidence seems to demonstrate Bonnet's creativity had been inspired by his influential friend and colleague: Georges Sorel (1847-1922).

In 1897, Sorel was a leading personality of French Socialism and a peculiar figure in the French intellectual landscape. A self-taught theoretician and 'erudite polymath' (Sand, 1985) also mocked as a 'queer thinker' (Gianinazzi, 2007, p. 92), Georges Sorel had resigned from the Civil Service in 1892 and had emerged out of nowhere as an atypical figure of socialism. Sorel is especially interesting to us, because of his training and professional career. A graduate of the School of Bridges and Roads and École Polytechnique, Sorel spent most of his career as civil servant delivering and managing railways. Furthermore, his biographer Pierre Andreu (1909-1987), in an effort to understand how he acquired his acute understanding of socialism, went to look at the 
list of books he borrowed at the municipal library of Perpignan from 1884 until 1891, his last posting. He could not find any reference to socialism: only books on architecture and archaeology (Andreu, 1953, p. 43). At this point of the demonstration, we can therefore safely assume that Sorel was familiar with the term infrastructure, from his experience with railways, and his readings in architecture and archaeology — the only three disciplines where the term was used at the time.

By studying a series of writings Sorel published between 1895 and 1897, we can witness how he 'metaphorised' infrastructure and effortlessly brought it into socialist parlance, where it became a canon of Marxism and social sciences. We find infrastructure used by Sorel:

(a) in a sequence of articles published in socialist journal Le Devenir Social (Sorel, 1896a, 1896b), including a critical review of Labriola's book on historical materialism (Sorel, 1896c);

(b) in a first excerpt of Labriola's book published in the same periodical (Labriola, 1896b);

(c) and last but certainly not least we find multiple occurrences of infrastructure in the foreword written by Sorel in December 1896 to the French translation of Labriola's book translated and published by Bonnet (Sorel, 1897).

Yet is it probably the very first occurrence of infrastructure under the quill of Georges Sorel, in 1895, that I find the most enlightening. In a critical review titled 'The Theories of Mr. Durkheim', Sorel used infrastructure to describe the most profound sediments of social phenomena. And then in a footnote that seems to justify his use of infrastructure in such an atypical context, he writes:

Architecture provides a good illustration: the shapes of buildings, their ornaments, what is the most visible, constitute the elements on which your average thinker 
bases their thinking; — quite the opposite, history deals with modes of construction, technical processes, assemblage of materials. In archaeological treatises produced by professors, the former point of view is the one that prevails. Artists are more interested in the latter. ${ }^{21}$ (Sorel, 1895, p. 159)

In the following years, the architectural metaphor coined by Sorel blossomed. Bonnet used it in his translation of Labriola, as we already saw. Then Charles Andler (1866-1933), who had met and befriended Sorel in 1897 following his work on Labriola's book, started using the word liberally - in several articles, conferences, classes, and translations such as the Communist Manifesto's, that he published in 1901 (Andler, 1897, 1901; Marx \& Engels, 1901). Andler, a Germanist and Professor at Collège de France was then seen as one of the best specialists of Marx — though not a Marxist himself. Unlike many other students of Marx, including Sorel, Andler could read Marx's texts in their original version and had therefore a much wider access to Marx's writings. ${ }^{22}$

I have not found any other documents before Sorel's articles of 1895-1897 that used infrastructure in a metaphoric way. This fact, and the biographical elements

${ }^{21}$ Original citation: 'L'architecture fournit un bon exemple : les formes des édifices, les ornements, ce qui est le plus apparent, constituent les éléments de raisonnement pour le vulgarisateur ; - au contraire, l'histoire s'occupe de la construction, des procédés techniques, des combinaisons de matériaux. Dans les traités d'archéologie faits par les professeurs, le premier point de vue domine encore. Les artistes se placent au second.'

${ }^{22}$ On Sorel, Andler and the reception of Marx in 1890-1900s' France, see Andreu (1953), Sand (1985), Prochasson (2005), Gianinazzi (2007), Cahen (1994, 2011). 
presented earlier, comfort the hypothesis that Georges Sorel was the first to use infrastructure in such a way.

At the turn of the $19^{\text {th }}$ century, thanks to the literary imagination of a railway engineer turned leading self-taught thinker of socialism, infrastructure quietly hijacked the debate on historical materialism and escaped its limited technical domains of railway engineering, architecture and archaeology. The metaphor initially pertained to Marxism, yet almost instantly slipped away and caught up with social sciences as a successful architectural sociotechnical metaphor.

\section{Infrastructure as metaphor in social sciences}

In the early $20^{\text {th }}$ century, from a figure of speech that could have remained restricted to socialist circles, 'infrastructure' once again expanded and percolated to other disciplines. The conceptual parable was so strong, so appealing, so accurate, that it ended up building a life of its own. I have systematically read all occurrences of 'infrastructure' sorted chronologically that came up with a text search on Gallica in order to trace the evolution in its meaning.

It is once again important to remind ourselves of the political and social context of the early $20^{\text {th }}$ century. Next to political movements such as socialism which called for 'social consciousness', a number of 'new' social sciences were emerging. Psychology, for instance, aimed at understanding the links between consciousness and subconsciousness; sociology, looked at broad trends to understand human beings as groups and what determined groups or individuals' behaviours. The image of an 'infrastructure' - may it be technological, political, moral, or a dormant consciousness - determining a 'superstructure', the visible aspect of a society, would have been highly striking, fashionable, modern: it tapped into the omnipresent technical 
imaginary of railway expansion, whilst illustrating an important intellectual trend at the turn of the century.

In the 1900s, 'infrastructure' remains mainly associated to railway, but its meaning evolve quickly. Below are three examples that illustrate this emancipation of infrastructure from Marxism and indeed railway engineering. Philosopher and sociologist Georges Palante (1862-1925) writes in 1901

Social economy is very close to enabled Psychology $[\ldots]$. As it is nothing else but management of needs and vital interests that, in human nature, are the infrastructure of the superficial psychological development. ${ }^{23}$ (Palante, 1901, p. 55)

A second example is Alfred Fouillée (1838-1912), a philosopher whose concept of idéeforce was very popular at the time. He writes in his 1903 book A psychological sketch of European peoples [Esquisse psychologique des Peuples Européens]:

One does most especially witness the social superstructure, the conscious direction of the group, the other sees most especially the social infrastructure, the subconscious pressure that goes from the bottom then up. $^{24}$ (Fouillée, 1903, p. 468)

And later:

${ }^{23}$ Original citation: 'L'Économie sociale touche de près à la Psychologie [...]. Car elle n'est autre chose qu'une gestion des besoins et des intérêts vitaux qui, dans la nature humaine, sont l'infrastructure de tout le développement psychologique supérieur.'

${ }^{24}$ Original citation: 'L'un [le comtisme français] voit surtout la superstructure sociale, la direction consciente de l'ensemble, l'autre [le marxisme allemand] voit surtout l'infrastructure sociale, la pression inconsciente qui s'exerce de bas en haut.' 
Two elements express, each in their own way, the character of a people: the study of its inferior and superior layers. The former is like the infrastructure of the national spirit; they represent the subconscious part $[\ldots] .{ }^{25}$ (Fouillée, 1903, p. 505)

Finally, another example from Jean Jaurès who writes in his 1911 classic,

\section{L'Armée Nouvelle [The New Army]:}

Napoleon has certainly been the most prodigious worker in his time. Yet, he has fallen, despite his work and genius. All the Caesars of capital will end like him, less quickly than him, because their power rests on stronger foundations, on all the infrastructure of the social system, and their destiny is more directly linked than Napoléon's to a vast ensemble. ${ }^{26}$ (Jaurès, 1911, p. 483)

Critics or followers, Socialists, Marxists, or social scientists - these three intellectuals and others who used the term infrastructure in the first years of the $20^{\text {th }}$ century were all well aware of the discussion on historical materialism that had taken place just a few years before. They had read Sorel, Andler, Labriola and the books

${ }^{25}$ Original citation: 'Deux éléments servent, chacun pour sa part, à manifester et à apprécier le caractère d'un peuple : l'étude des couches inférieures et celle des couches supérieures. Les premières sont comme l'infrastructure du caractère national ; elles en représentent la partie presque inconsciente $[\ldots]$.'

${ }^{26}$ Original citation: 'Napoléon a été sans doute le plus prodigieux travailleur de son temps. Il est tombé cependant malgré ton travail et malgré son génie. Tous les Césars du capital passeront comme lui, moins vite que lui, car leurs puissance repose sur de plus solides assises, sur toute l'infrastructure résistante d'une système social et leur destin est plus fortement lié que celui de Napoléon à tout un vaste ensemble.' 
published by Alfred Bonnet. Consciously or not, by their writing, they were bringing infrastructure to a new audience.

From the 1900s onwards, the use of infrastructure for its metaphorical value manifestly increased. The relationship to Marx or socialism was now tenuous. It even developed outside of social sciences. Take for instance this article on functional calculus by Maximilien Winter (1871-1935), a philosopher of mathematics, published in 1913. He concludes by writing about 'the infrastructure of the Universe' (Winter, 1913, p. 510). Or this 1912 unsigned article in a periodical dedicated to music: in a concert review, the critic talks of 'literary infrastructure' and later the 'rhythmic infrastructure' of the piece ('Le Mois', 1912, p. 61). Two examples, amongst many others, of the momentum gained by the idea of infrastructure.

The use of infrastructure was also quite distinctive in economics. In this 1910 report on Le Havre's harbour, an engineer employed by Le Havre's Chamber of Commerce writes:

The equipment of France's harbours. - In France, the commercial harbours, managed by maritime engineers, are created by the State.

The former is therefore in charge of building and maintaining the maritime buildings; said otherwise, it is the State that has to care for the harbours' infrastructure..$^{27}$ (Jacquey, 1910, p. 67- original emphasis)

${ }^{27}$ Original citation: 'L'outillage de ports en France. - En France, les ports de commerce, dont les ingénieurs des ports maritimes assurent la direction exclusive, sont créés par l'État. 
Another example, a 1919 newspaper article, 'The Colonial Post-War

Programme', written by Senator Lucien Hubert (1868-1938)

The task that I would call the economic 'equipment' of a colony is vastly more stretched that one imagines. The railway networks, the ports, the commercial navy constitute the 'infrastructure', so to speak: then remains the 'suprastructure', that has its importance. So that a colony can 'live' with its homeland $[\ldots ..] .^{28}$ (Hubert, 1919, p. 571)

All emphases in these two documents are original: for Le Havre's engineer, the italics that highlight the word infrastructure, and in Hubert, the quotation marks surrounding 'equipment', 'infrastructure' and 'suprastructure' [sic]. The punctuation and typographical choices (and errors) clearly denote the novelty and/or atypical use of these words in this context.

By the 1930s, in French, infrastructure had taken off to reach a whole new semantic level. From the niche technical term limited to railway engineering, architecture and archaeology, it had blossomed. It was now more complex, used in different contexts, disciplines and by varied audiences. And it had quickly been adopted by a new transport technology: aviation. Infrastructure would have then described all

Ce dernier est donc seul chargé de construire et d'entretenir les ouvrages maritimes; en d'autres termes ; en d'autres termes, c'est lui qui a le souci de l'infrastructure des ports.'

${ }^{28}$ Original citation: 'La tâche de ce que j'appellerai « l'équipement » économique d'une colonie est infiniment plus étendue qu'on ne l'imagine. Les réseaux ferrés, les ports, la marine de commerce constituent «l'infrastructure », si l'on veut ; reste encore la « suprastructure », qui a son importance. Pour qu'une colonie « vive » avec sa métropole $[\ldots]$. 
ground equipment (airfields, airports, etc.). The same way it semantically supported the spatial project associated with railway expansion in France and its colonies, 'infrastructure' now bore a similar role with the expansion of air travels. When looking at early maps for air travels, for instance the 'Air infrastructure of Indochina' printed in 1939 , one is struck by the metonymic power of this representation: the infrastructure here, is the sum of abstract lines between Saigon and Hanoi, an illustration of the colonial project, an illustration of its modernity (Service géographique de 1'Indo-Chine, 1939).

It is through defence and aviation that 'infrastructure' eventually entered the English language. After WWII, the North Atlantic Treaty Organization (NATO) organised the defence of Europe (against the Soviet Union). A network of airfields was programmed to be built across Western Europe with the vast majority of them in France. The New York Times reports in 1951 that:

The French called this new network of air bases the 'infrastructure', meaning the foundation or basis for the Allies' air power and the name has been adopted by the treaty organization. ('French Push Work on Air Bases', 1951- my emphasis)

Here the emphasis is mine, in order to highlight their echoes to Marxist lexicon. Meanwhile, the word 'infrastructure' is here presented as a novelty, brought in by the French. Several other news reports published in the New York Times in 1950-1951 (see for instance 'Labor Upheld', 1950; Krock, 1951a, 1951b) and secondary sources (North Atlantic Treaty Organization, 2001; Carse, 2017) confirm this hypothesis. In 1952, the New York Times writes that "the word "infrastructure", a favourite bureaucratic morsel 
in the language of European defence' is 'baffling' to Secretary of State Dean Acheson (1893-1971). He is quoted saying

One thing I can't explain to you is how these facilities came to be called by the name 'infrastructure.' But despite this heavy handicap, good progress was made on this issue, too. ('Use of "Infrastructure" Is Baffling to Acheson', 1952)

At the same time, the term kept gaining always more momentum as a metaphor in French. It seemed to be especially popular in policy and politics, and now went way beyond the issue of transport. In a 1959 article published by the French Gymnastic and Sport Federation's weekly publication, the expression 'sport infrastructure' is used (Berthelot, 1959). The same year, in the same publication, an article relays the petition of the Comite Pierre de Coubertin sent to the Assemblée Nationale whose first principle is

That we take the opportunity offered by the ongoing reform on education to $[\ldots]$ give to physical and sport education in open air the position that has been refused to it until now, and that is justified by its beneficial impact on youth's health, character and moral standards.

And one of the subsequent demands is:

$1^{\circ}$ Give to the Country the sport infrastructure it lacks: 'Stadia, swimming pools, sports hall' etc. ${ }^{29}$ ('Le Sport et l'Assemblée National', 1959, p. 5)

${ }^{29}$ Original citation: 'Que l'on profite de la réforme de l'enseignement en cours pour [...] que l'on donne à l'éducation physique et sportive et de plein air la place qu'on lui a refusé 
The expression 'sport infrastructure' would come as crystallisation of a relationship between material aspects of France's sport equipment, and the health and moral standards of its youth. It linked the future of France to its network of sports facilities.

\section{Discussion and conclusion}

I set out to uncover the etymological and intellectual origins of 'infrastructure'. From the evidence presented in this article, it seems that 'infrastructure' went through three semantic states. It appeared in the 1850 s as a concept infused with Saint-Simonian ideal and materialist philosophy. Apparently coined by the entourage of the Brothers Pereire, it answered the bill of 1842 that aimed at stimulating the expansion of railway in France by having the State bearing the costs of all operations taking place 'below' groundland acquisitions, levelling, building of tunnels and bridges. It was adopted by the domain of railway, its financiers, its investors and legislators. At the same time, it became used in architecture and archaeology to describe the structures of an edifice, or the elements of an archaeological site that lied below ground.

In the 1890s, retired engineer and leading socialist intellectual Georges Sorel transformed the term with much creative license and brought it into social sciences as a translation of Marx's concept of 'reale Basis'. Then from the 1900s and throughout the first half of the twentieth century, in French mostly, infrastructure escaped the sole context of Marxist studies and socialism to become a fully-grown architectural

jusqu'à présent, et que justifie son action bienfaisante sur la santé, le caractère et le comportement moral des jeunes $[\ldots] ; 1^{\circ}$ Donner au Pays l'infrastructure sportive qui lui manque : « Stades, piscines, gymnases », etc.’ 
metaphor used in literature, music, the arts, but also politics and economics. Materialist in its essence, linked to Saint-Simon, Marx, and others, the idea that a country's economic and political system rests on a networked physical infrastructure crystallised then. It became durably anchored in a sociotechnical imaginary that still animates us today. Metaphysically, it encapsulated the idea that a country's superstructure - its moral, ethics, social and legal system, its prosperity — were determined by physical networks, assemblage of equipment and technologies.

Once it entered the English lexicon in the 1950s, the parable of infrastructure thrived across different languages —English, German, Spanish, amongst others. The rise of development economics after WWII and their main institutions - the International Monetary Fund, World Bank, United Nations, all created in 1945-embraced the concept of infrastructure to push the idea that a country could reach 'development' by investing in fixed assets, physical networks and equipment. The correlation between the facilities of a country - the quality of its roads, the coverage of its phone network, the resilience of its electricity grid — and its prosperity, wealth, but also its standards of moral and ethics then became more transparent (Rankin, 2009; Rist, 2014). One of the pinnacle of the stretched use of the term 'infrastructure' was arguably reached with Ronald Reagan's speech on the 'infrastructure of democracy', delivered at the UK House of Common in 1982 and which led to the creation of the National Endowment for Democracy in 1983 (Reagan, 1982). Money was democracy; democracy was money. Rankings, return on investment, CAPEX, evaluation, data, 'metricization' of space and people - the infrastructural paradigm brought with it a cortege of jargon, tools and policy mechanisms: an infrastructural mindset (Easterling, 2014).

This paper sought out to produce an archaeology of 'infrastructure' focusing specifically on a period ranging from 1842 until 1951. Its first contribution is to correct 
repeated historical approximations regarding the timeline of the term 'infrastructure' in the time period studied. Second, it demonstrates the direct relationship between the 'infrastructure' that emerged in post-WWII English and the historical materialism of Marx. Third, contradicting Rankin, this paper has showed that from as early as the 1890s, infrastructure 'becomes recognizable as a concept relating engineering to larger socioeconomic concerns' (Rankin, 2009, p. 63) and that by the 1910s it is a staple of economic policy in France. And in a final, last-minute element to underline, the research developed in this article tends to demonstrate that the Biden administration's all-encompassing understanding of infrastructure is backed by the term's history.

This paper is a call to critically question the transparency, obviousness, the ubiquity of 'infrastructure' in everyday language and social theories. By tracing its blueprint, this essay has sought to open intellectual doors, critical pipes, scholarly sockets in order to dissect the metaphor of infrastructure. It is a dense, necessarily multi- and trans-disciplinary research endeavour whose surface this paper has barely scratched. It brings further questions, such as: How does the relationship to Marxism and the updated timeline proposed in this paper informs our critical historical understanding of the emergence of development economics in the 1950s? What is the contribution of this enriched understanding of infrastructure to real and imagined underground environments (Williams, 2008)? And to a critical approach to sociotechnical imaginaries and our 'dreamscapes of modernity' (Jasanoff \& Kim, 2015)? How can we refine our historical understanding of the post-war 'boom' of 'infrastructure' in development economics to the colonial projects of $19^{\text {th }}$ and $20^{\text {th }}$ centuries?

The idea of a spatial, or metaphysical dualism between what is below and above did not start with the concept of infrastructure - it links ancient religions to postmodern 
philosophies. Yet, infrastructure as an expression of modernity crystallised a sociotechnical imaginary, a relation between technology, space and power. I hope that by developing an archaeology of this term, this article has contributed prying open the semantic black box to our infrastructural age. 


\section{References}

Accent's Way English with Hadar. (2017). The Most Mispronounced Words in Tech [part 1]. Retrieved from https://www.youtube.com/watch?v=-qWiBtYY04A

Alonzo, É. (2018). L'Architecture de la voie. Marseille \& Champs-sur-Marne: Éditions Parenthèses \& École de la ville et des territoires.

Althusser, L. (1965). Pour Marx. Paris: François Maspero.

American Association of Geographers. (2001, March 27). 2001 Annual Meeting-Program. Retrieved from http://www.aag.org/galleries/conference-files/AAG2001_Printed_Program.pdf

American Association of Geographers. (2019, April 3). 2019 Annual Meeting - Program. Retrieved from http://www.aag.org/galleries/conference-files/AAG_2019_DC_print_program.pdf

Amin, A. (2014). Lively infrastructure. Theory Culture and Society, 31(7-8), 137-161. https://doi.org/10.1177/0263276414548490

Andler, C. (1897). La conception matérialiste de l'histoire. Revue de Métaphysique et de Morale, $644-$ 658.

Andler, C. (1901). Introduction Historique et Commentaire. In Bibliothèque socialiste: Vol. 8-10. Le Manifeste Communiste (Vols 1-1). Paris: Société Nouvelle de Librairie et d'Édition. Retrieved from http://gallica.bnf.fr/ark:/12148/bpt6k552462

Andreu, P. (1953). Notre maître, M. Sorel. Paris: B. Grasset. Retrieved from http://gallica.bnf.fr/ark:/12148/bpt6k33574504

Banham, R. (1988). TVA: l'ingegneria dell'utopia. Casabella, (542-3), 74-81.

Barthes, R. (1957). Mythologies. Paris: Seuil.

Berthelot, P. (1959, May 31). Le problème de la natation. Les Jeunes, p. 5.

Biden, J. (2021, April 12). Remarks by President Biden at a Virtual CEO Summit on Semiconductor and Supply Chain Resilience [The White House]. Retrieved from https://www.whitehouse.gov/briefing-room/speeches-remarks/2021/04/12/remarks-by-presidentbiden-at-a-virtual-ceo-summit-on-semiconductor-and-supply-chain-resilience/

Bijker, W. E., Hughes, T. P., \& Pinch, T. J. (Eds.). (1987). The Social construction of technological systems: New directions in the sociology and history of technology. Cambridge, Mass. ; London: MIT Press.

Björkman, L. (2015). Pipe Politics, Contested Waters: Embedded Infrastructures of Millennial Mumbai. Duke University Press. https://doi.org/10.1215/9780822375210

Bowker, G. C. (1994). Information Mythology and Infrastructure. In L. Bud-Frierman (Ed.), Information acumen: The understanding and use of knowledge in modern business (pp. 231-247). London ; New York: Routledge.

Bowker, G. C., \& Star, S. L. (1999). Sorting things out: Classification and its consequences. Cambridge, Mass.: The MIT Press.

Bricka, C. (1891). Notes prises au cours de chemins de fer. Retrieved from https://patrimoine.enpc.fr/document/ENPC02_COU_4_19543_1891?image=5\#bibnum

Bucciarelli, L. (1994). Designing engineers. Cambridge, Mass. ; London: MIT Press.

Bud-Frierman, L. (Ed.). (1994). Information acumen: The understanding and use of knowledge in modern business. London; New York: Routledge.

Cahen, J. (1994). La réception de l'œuvre de Karl Marx par les économistes français (1871-1883). Mil neuf cent. Revue d'histoire intellectuelle (Cahiers Georges Sorel), 12(1), 19-50. https://doi.org/10.3406/mcm.1994.1107

Cahen, J. (2011). Les premiers éditeurs de Marx et Engels en France (1880-1901). Cahiers d'histoire. Revue d'histoire critique, (114), 20-37.

Carse, A. (2017). Keyword: Infrastructure: How a humble French engineering term shaped the modern world. In P. Harvey, C. Bruun Jensen, \& A. Morita (Eds.), Infrastructures and social complexity: A companion (pp. 27-39). London: Routledge, Taylor \& Francis Group. 
Castells, M. (1989). The informational city: Information technology, economic restructuring, and the urban-regional process. Blackwell.

Castells, M. (1996). The rise of the network society. Oxford: Blackwell.

Chevalier, M. (1852a). Chemins de fer (Vols 1-1). Paris: Guillaumin. Retrieved from http://gallica.bnf.fr/ark:/12148/bpt6k54526780

Chevalier, M. (1852b). Chemins de fer. Paris: Guillaumin.

Collins A-Z. (2017). How to pronounce INFRASTRUCTURE in British English. Retrieved from https://www.youtube.com/watch?v=jkwoJUXv_NE

Coutard, O. (1999). The Governance of Large Technical Systems. London; New York: Routledge.

Croce, B. (1898). Essai d'interprétation et de critique de quelques concepts du marxisme. Le Devenir Social, 4(2), 97-126.

Croce, B. (1900). Materialismo storico ed economia marxistica. Palermo: Sandron.

Cronier, P.-N. (1847). Précis sur les chemins de fer de France: Moyens financiers d'achever sans retard l'établissement du réseau, de raffermir le crédit, de garantir les intérêts compromis dans les opérations des chemins de fer (Vols 1-1). Paris: L. Mathias. Retrieved from http://gallica.bnf.fr/ark:/12148/bpt6k9641911k

C-Span. (2021, April 12). President Biden Remarks at Virtual CEO Summit. C-Span. Retrieved from https://www.c-span.org/video/?510736-1/president-biden-addresses-virtual-ceo-summit

Davies, H. (2015). Emile and Isaac Pereire: Bankers, socialists and Sephardic Jews in nineteenthcentury France / Helen M. Davies. Manchester: University Press.

Easterling, K. (2014). Extrastatecraft: The Power of Infrastructure Space. Verso Books.

Edwards, P. N. (1998). Y2K: Millennial reflections on computers as infrastructure. History and Technology, 15(1-2), 7-29. https://doi.org/10.1080/07341519808581939

Engels, F. (1908). Socialism: Utopian and Scientific (E. Aveling, Trans.). Chicago: Charles H. Kerr Company. http://www.gutenberg.org/files/39257/39257-h/39257-h.htm.

Filter, J. (2017, January 3). How to Export Data from Google Ngram Viewer. Retrieved 14 April 2020, from Johannes Filter website: https://johannesfilter.com/how-to-export-data-from-googlengram-viewer/

Foucault, M. (1955). Introduction. In Le Rêve et l'existence. Paris: Desclée, de Brouwer.

Foucault, M. (1971). The Order of Things. New York: Pantheon Books. Retrieved from https://monoskop.org/images/a/a2/Foucault_Michel_The_Order_of_Things_1994.pdf

Foucault, M. (1984). The Foucault reader (P. Rabinow, Ed.). New York: Pantheon Books.

Fouillée, A. (1903). Esquisse psychologique des peuples européens. Retrieved from https://gallica.bnf.fr/ark:/12148/bpt6k432010d

French push work on air bases. (1951, July 18). New York Times.

Gallica. (n.d.). 6 millions de documents numérisés dans Gallica. Retrieved 5 April 2020, from https://gallica.bnf.fr/blog/05022020/6-millions-de-documents-numerises-dansgallica? mode $=$ desktop

Gandy, M. (2014). The fabric of space: Water, modernity, and the urban imagination. Cambrige, Mass.: The MIT Press.

Gianinazzi, W. (2007). Georges Sorel, un homme de controverses? Mil neuf cent. Revue d'histoire intellectuelle, $n^{\circ} 25(1), 91-100$.

Google. (2019, October 17). 15 years of Google Books. Retrieved 5 April 2020, from Google website: https://blog.google/products/search/15-years-google-books/

Graham, S., \& Marvin, S. (2001). Splintering urbanism. London; New York: Routledge.

Grande société des chemins de fer russes. Documents officiels. (1858). Paris: imp. P. Dupont. Retrieved from http://gallica.bnf.fr/ark:/12148/bpt6k9782126x

Hall, S., King, J., \& Finlay, R. (2017). Migrant infrastructure: Transaction economies in Birmingham and Leicester, UK. Urban Studies, 54(6), 1311-1327. https://doi.org/10.1177/0042098016634586

Hubert, L. (1919, August 30). Le programme colonial d'après-guerre. La Revue Hebdomadaire, 35.

Inventing 'infrastructure': tracing the etymological blueprint of an omnipresent sociotechnical metaphor (preprint) Justinien TRIBILLON, The Bartlett School of Planning, University College London — j.tribillon@ucl.ac.uk 
Hughes, T. P. (1983). Networks of power: Electrification in Western society, 1880-1930. Baltimore; London: Johns Hopkins University Press.

Jacquey, M. L. (1910). L’Outillage du Port du Havre. In Le Havre et le département de la SeineInférieure (pp. 67-93). Paris: C. Delagrave. Retrieved from http://gallica.bnf.fr/ark:/12148/bpt6k165133g

Janets, J. (1857, March 8). Chemins de Fers Russes. La Gazette de La Bourse.

Jasanoff, S., \& Kim, S.-H. (2015). Dreamscapes of Modernity. Chicago: University of Chicago Press. Retrieved from https://press.uchicago.edu/ucp/books/book/chicago/D/bo20836025.html

Jaurès, J. (1911). L'armée nouvelle. Paris: J. Rouff. Retrieved from http://gallica.bnf.fr/ark:/12148/bpt6k932623s

Jaurès, J., \& Lafargue, P. (1895). Idéalisme et matérialisme dans la conception de l'histoire: Conférence de Jean Jaurès et réponse de Paul Lafargue. Paris: Groupe des Étudiants Collectivistes (Adhérent à l'Agglomération Parisienne du Parti Ouvrier). (https://catalogue.bnf.fr/ark:/12148/cb307132273).

Kaika, M., \& Swyngedouw, E. (2000). Fetishizing the modern city: The phantasmagoria of urban technological networks. International Journal of Urban and Regional Research, 24(1), 120-138. https://doi.org/10.1111/1468-2427.00239

Keane, S. (2006). Disaster Movies: The Cinema of Catastrophe. New York: Columbia University Press.

Krock, A. (1951a, September 26). Bringing the Political Lexicon Up to Date. New York Times.

Krock, A. (1951b, October 11). Bringing the Political Lexicon Up to Date: II. New York Times.

Labica, G., \& Bensussan, G. (1982). Dictionnaire critique du marxisme. Paris: Presses Universitaires de France.

Labor Upheld. (1950). New York Times.

Labriola, A. (1896a). Del materialismo storico. Dilucidazione preliminare. Rome: Loescher.

Labriola, A. (1896b). La théorie des facteurs historiques et la conception matérielle de l'histoire. Le Devenir Social : Revue Internationale d'économie, d'histoire et de Philosophie, 2(9), 818-827.

Labriola, A. (1897). Essais sur la conception matérialiste de l'histoire (1st ed.; A. Bonnet, Trans.). Paris: V. Giard et E. Brière.

Larkin, B. (2013). The Politics and Poetics of Infrastructure. Annual Review of Anthropology, 42, $327-$ 343.

Latour, B. (1991). Nous n'avons jamais été modernes. Paris: La Découverte.

Latour, B. (1992). Aramis, ou, L'amour des techniques. Paris: La Découverte.

Latour, B., \& Hermant, E. (1998). Paris, ville invisible. Le Plessis-Robinson; Paris: La Découverte.

Le Mois. (1912, January 15). Revue Musicale S.I.M., 55.

Le sport et l'Assemblée National. (1959, April 29). Les Jeunes, p. 5.

Littré, É., \& Devic, M. (1886). Infrastructure. In Dictionnaire de la langue française: Supplément. Hachette. Retrieved from https://gallica.bnf.fr/ark:/12148/bpt6k5406583t

Loan translation. (2014). In The Oxford Dictionary of English Grammar. Oxford University Press. Retrieved from http://www.oxfordreference.com/view/10.1093/acref/9780199658237.001.0001/acref9780199658237-e-805

Maringanti, A., \& Jonnalagadda, I. (2015). Rent gap, fluid infrastructure and population excess in a gentrifying neighbourhood. City, 19(2-3), 365-374. https://doi.org/10.1080/13604813.2015.1016341

Marx, K. (1859). Zur Kritik der politischen Ökonomie. Berlin: Franz Duncker.

Marx, K. (1867). Das Kapital. Kritik der politischen Oekonomie. Hamburg: Verlag von Otto Meisner.

Marx, K. (1872). Le Capital (J. Roy, Trans.). Paris: Maurice Lachatre et Compagnie.

Marx, K. (1879). Il capitale (C. Cafiero, Trans.). Milano: Bignami. 
Marx, K. (1885). Das Kapital. Kritik der politischen Oekonomie. Buch II: Der Cirkulationsprocess des Kapitals. (Friedrich Engels, Ed.). Hamburg: Verlag von Otto Meisner.

Marx, K. (1887). Capital: A Critical Analysis of Capitalist Production (S. Moore \& E. Aveling, Trans.). S. Sonnenschein, Lowrey, \& Company.

Marx, K. (1894). Das Kapital. Kritik der politischen Oekonomie. Buch III: Der Gesammtprocess der kapitalistischen Produktion. (Friedrich Engels, Ed.). Hamburg: Verlag von Otto Meisner.

Marx, K. (1897). Zur Kritik der Politischen Oekonomie (K. Kautsky, Ed.). Stuttgart: J. H. W. Dietz Nachf. (https://catalog.hathitrust.org/Record/101699105).

Marx, K. (1899). Critique de l'économie politique (L. Rémy, Trans.). Paris: Schleicher frères.

Marx, K. (1904). A contribution to the critique of political economy (N. I. Stone, Trans.). Chicago: Charles H. Kerr Company. Retrieved from http://hdl.handle.net/2027/nyp.33433075925671

Marx, K. (1909). Contribution à la critique de l'économie politique (L. Lafargue, Trans.). Paris: V. Giard et E. Brière. (http://gallica.bnf.fr/ark:/12148/bpt6k1135015).

Marx, K., \& Engels, F. (1901). Le Manifeste communiste (C. Andler, Trans.). Retrieved from https:/gallica.bnf.fr/ark:/12148/bpt6k55247d

Marx, K., Lefebvre, H., Guterman, N., Nizan, P. Y., \& Duret, J. (1934). Morceaux choisis. Paris: Gallimard.

Mattioli, G. (2019, February 26). What caused the Genoa bridge collapse - and the end of an Italian national myth? The Guardian. Retrieved from https://www.theguardian.com/cities/2019/feb/26/what-caused-the-genoa-morandi-bridgecollapse-and-the-end-of-an-italian-national-myth

Michel, J.-B., Shen, Y. K., Aiden, A. P., Veres, A., Gray, M. K., Team, T. G. B., ... Aiden, E. L. (2011). Quantitative Analysis of Culture Using Millions of Digitized Books. Science, 331(6014), 176182. https://doi.org/10.1126/science.1199644

Neumann, L. J., \& Star, S. L. (1996). Making Infrastructure: The Dream of a Common Language. PDC, $231-240$.

North Atlantic Treaty Organization. (2001). NATO Security Investment Programme is the SHARING of Roles, Risks, Responsibilities, Costs and Benefits. Bruxelles: NATO.

Oliver, J. (2015, March 1). Infrastructure. New York: HBO.

Palaa, G. (1887). Dictionnaire législatif et réglementaire des chemins de fer. Paris: Marchal et Billard. Retrieved from https://gallica.bnf.fr/ark:/12148/bpt6k57280971

Palante, G. (1901). Précis de sociologie. Paris: F. Alcan. Retrieved from https://gallica.bnf.fr/ark:/12148/bpt6k6154620w

Paltrinieri, L. (2015). Archéologie. Le Telemaque, $N^{\circ} 48(2), 15-30$.

Paul N. Edwards. (2021, April 14). History of 'infrastructure': A thread. It's an old term, originally used in a military context to refer to large, fixed facilities such as air bases. Here's an ngram of 'military' + 'infrastructure' thru 1950. Clearly post-WWII was the big moment here. [Tweet]. Retrieved 18 April 2021, from@AVastMachine website: https://witter.com/AVastMachine/status/1382395605394235392

Picon, A. (1992a). French architects and engineers in the Age of Enlightenment. Cambridge: Cambridge University Press.

Picon, A. (1992b). La notion moderne de structure. Les Cahiers de La Recherche Architecturale, 29, $101-110$.

Picon, A. (2007). French Engineers and Social Thought, 18-20th Centuries: An Archeology of Technocratic Ideals. History and Technology, 23(3), 197-208. https://doi.org/10.1080/07341510701300262

Picon, A. (2014). La ville des réseaux-Un imaginaire politique. Paris: Manucius.

Picon, A. (2018). Urban Infrastructure, Imagination and Politics: From the Networked Metropolis to the Smart City. International Journal of Urban and Regional Research, 42(2), 263-275. https://doi.org/10.1111/1468-2427.12527 
Prochasson, C. (2005). L'invention du marxisme français. Paris: La Découverte. Retrieved from https://www.cairn.info/resume.php?ID_ARTICLE=DEC_BECKE_2005_01_0426

Proudhon, P.-J. (1845). De la concurrence entre les chemins de fer et les voies navigables. Paris: Guillaumin.

Rankin, W. J. (2009). Infrastructure of the international governance of economic development, 19501965. In J.-F. Auger, J. J. Bouma, \& R. Künneke (Eds.), Internationalization of infrastructures (pp. 61-75). Delft: TU Delft.

Reagan, R. (1982, June). Text of President Ronald Reagan's Westminster Address - National Endowment for Democracy. Retrieved 31 October 2018, from https://www.ned.org/promotingdemocracy-and-peace/

Renu, D., McFarlane, C., \& Graham, S. (2014). The Politics of Open Defecation: Informality, Body, and Infrastructure in Mumbai. Antipode, 47(1), 98-120. https://doi.org/10.1111/anti.12117

Resis, A. (1970). Das Kapital Comes to Russia. Slavic Review, 29(2), 219-237. JSTOR. https://doi.org/10.2307/2493377

Revue archéologique (Vols 1-XXI). (1893). Paris: Ernest Leroux. Retrieved from http://gallica.bnf.fr/ark:/12148/cb32856350w/date

Rieber, A. J. (1973). The Formation of La Grande Société des Chemins de Fer Russes. Jahrbücher Für Geschichte Osteuropas, 21(3), 375-391. JSTOR. Retrieved from JSTOR.

Rist, G. (2014). The history of development from Western origins to global faith (Fourth edition.). London ; New York: Zed Books.

Robb, G. (1992). The Railway Mania. In White-Collar Crime in Modern England: Financial Fraud and Business Morality, 1845-1929. 31-55: Cambridge University Press. https://doi.org/10.1017/CBO9780511522789.003

Royaume de France. Loi du 11 juin 1842 relative à l'établissement des grandes lignes de chemins de fer. , (1842).

Sand, S. (1985). L'illusion du politique: Georges Sorel et le débat intellectuel 1900. Paris: La découverte.

Schultz, J. (2012). Twentieth-century borrowings from French into English - an overview: On the continuing influence of French on the English lexicon. English Today, 28(2), 3-9. https://doi.org/10.1017/S0266078412000089

Service géographique de l'Indo-Chine. (1939). Infrastructure Aérienne de l'indo-Chine. Hanoi.

Silver, J. (2014). Incremental infrastructures: Material improvisation and social collaboration across postcolonial Accra. Urban Geography, 35(6), 788-804. https://doi.org/10.1080/02723638.2014.933605

Simone, A. (2004). People as Infrastructure: Intersecting Fragments in Johannesburg. Public Culture, 16(3), 407-429. https://doi.org/10.1215/08992363-16-3-407

Simone, A. (2015). Afterword: Come on out, you're surrounded: The betweens of infrastructure. City, 19(2-3), 375-383. https://doi.org/10.1080/13604813.2015.1018070

Simone, A. (2021). Ritornello: "People as Infrastructure". Urban Geography, 0(0), 1-8. https://doi.org/10.1080/02723638.2021.1894397

Société languedocienne de géographie. (1890). Bulletin [Bulletin]. Retrieved from https://gallica.bnf.fr/ark:/12148/bpt6k415252h

Sorel, G. (1895). Les Théories de M. Durkheim (suite et fin). Le Devenir Social, 1(2), 148-180.

Sorel, G. (1896a). Études sur Vico. Le Devenir Social, 2(9), 785-817.

Sorel, G. (1896b). La science dans l'éducation. Le Devenir Social : Revue Internationale d'économie, d'histoire et de Philosophie, 2(3), 208-239.

Sorel, G. (1896c). Revue Critique. Le Devenir Social : Revue Internationale d'économie, d'histoire et de Philosophie, 4(8-9), 761-766.

Sorel, G. (1897). Préface. In A. Bonnet (Trans.), Essais sur la conception matérialiste de l'histoire. Paris: V. Giard et E. Brière.

Sparavigna, A. C., \& Marazzato, R. (2015). Using Google Ngram Viewer for Scientific Referencing and History of Science. ArXiv:1512.01364 [Cs]. Retrieved from http://arxiv.org/abs/1512.01364

Inventing 'infrastructure': tracing the etymological blueprint of an omnipresent sociotechnical metaphor (preprint) Justinien TRIBILLON, The Bartlett School of Planning, University College London — j.tribillon@ucl.ac.uk 
Star, S. L. (1999). The Ethnography of Infrastructure. American Behavioral Scientist, 43(3), 377-391. https://doi.org/10.1177/00027649921955326

Star, S. L., \& Ruhleder, K. (1996). Steps Toward an Ecology of Infrastructure: Design and Access for Large Information Spaces. Information Systems Research, 7(1), 111-134. https://doi.org/10.1287/isre.7.1.111

Steele, W., \& Legacy, C. (2017). Critical Urban Infrastructure. Urban Policy and Research, 35(1), 1-6. https://doi.org/10.1080/08111146.2017.1283751

Superholly. (2018). 15 palabras dificiles de pronunciar en inglés. Retrieved from https://www.youtube.com/watch?v=J_9MkKAFrFw

Tankersley, J., \& Smialek, J. (2021, April 5). Biden Plan Spurs Fight Over What 'Infrastructure' Really Means. The New York Times. Retrieved from https://www.nytimes.com/2021/04/05/business/economy/biden-infrastructure.html

Trovalla, E., \& Trovalla, U. (2015). Infrastructure as a divination tool: Whispers from the grids in a Nigerian city. City, 19(2-3), 332-343. https://doi.org/10.1080/13604813.2015.1018061

Use of 'infrastructure' is baffling to Acheson. (1952, March 1). New York Times.

Vajda, J. (2008). Les Pereire et Nagelmackers, promoteurs du transport ferroviaire et du réseau hôtelier parisien, 1855-1900. Revue d'histoire des chemins de fer, (38), 27-44. https://doi.org/10.4000/rhcf.1256

van Laak, D. (1999). Der Begriff 'Infrastructur' und was er vor seiner Erfinding besagte. Archiv Für Begriffsgeschichte, 41, 280-299.

Verne, J. (1892). Le château des Carpathes. Paris: Hetzel. Retrieved from https://gallica.bnf.fr/ark:/12148/bpt6k6578041r

Verne, J. (1895). L'île à hélice. Paris: Hetzel. Retrieved from https://gallica.bnf.fr/ark:/12148/bpt6k6577509z

Williams, R. H. (2008). Notes on the underground: An essay on technology, society, and the imagination (New edition.). Cambridge, Massachusetts: The MIT Press.

Winner, L. (1980). Do Artifacts Have Politics? Daedalus, 109, 121-136.

Winter, M. (1913). Les principes du calcul fonctionnel. Revue de Métaphysique et de Morale, 462-510. 